\title{
Sir Roger Scruton: Good, Beautiful, True
}

\section{Steven Kessler}

I first encountered Roger Scruton through his foreword to Russell Kirk's biography of Edmund Burke. I had no idea who Sir Roger was, but after reading his brief three-page introduction, I knew he was a writer who required further investigation.

The first of his assertions that truly affected me was his explanation of the relationship between the living, the dead, and the unborn:

Society, Burke pointed out, is an open-ended partnership (he even said "contract") between generations. The dead and the unborn are as much members of society as the living. To dishonor the dead is to reject the relation on which society is built-the relation of obligation between generations. Those who have lost respect for their dead have ceased to be trustees of their inheritance. Inevitably, therefore, they lose the sense of obligation to the unborn. The web of obligations shrinks to the present tense. ${ }^{1}$

Sir Roger understood that our lives are indebted to our ancestors, and because of that, we have a corresponding obligation to our descendants. We are trustees of an inheritance, and as trustees, we are bound by a web of obligations that have not been negotiated but are nonetheless unbreakable duties. For the conservative, human beings come into this world burdened by obligations, and subject to institutions and traditions that contain within them a precious inheritance of wisdom, without which the exercise of freedom is as likely to destroy human rights and entitlements as to enhance them. For Scruton, citizens must

1 Roger Scruton, Rousseau (no date).

Steven Kessler received his Ed.D. from the University of Rochester in Higher Education Administration; stevenkessleremail@gmail.com. He is the Edmund Burke Society Fellow at the Russell Kirk Center for Cultural Renewal. Kessler last appeared in AQ with "Social Justice 101: Intro. to Cancel Culture" in the summer of 2021. 
[s]ee themselves as inheritors, not creators, of the order in which they participate, so that they may derive from it . . the conceptions and values which determine self-identity. They will see their extension in time from birth to death as taking on significance from civil stability: their world was not born with them, nor does it die when they depart from it. ${ }^{2}$

We are recipients of this inheritance we call civilization. It was given to us by the dead, and someday soon, we too will join them.

Sir Roger's continual emphasis on the dead, as well as his articulation of the fact that we, the living, will eventually depart, is a key element in his understanding of what makes life worth living. Our time on Earth is short, and this finite nature of the human condition is what causes us to create, to love, to sacrifice, and to forge a lasting legacy. Sir Roger delivered his sentiments on the subject with his typical elegance:

Mortality is inextricably woven into the human scheme of things: that our virtues and our loves are the virtues and loves of dying creatures; that everything that leads us to cherish one another, to sacrifice ourselves, to make sublime and heroic gestures is predicated on the assumption that we are vulnerable and transient, with only a fleeting claim on the things of this world. ${ }^{3}$

Our brief and fleeting claim to our terrestrial existence is the impetus to make heroic gestures and sacrifices, but it's not the sole cause. Another cause is our knowledge of the fragility of our existence.

This fragility is the essence of conservatism to Scruton. He distilled this essence in a short pithy aphorism: “Conservatism starts from a sentiment that all mature people can readily share: the sentiment that good things are easily destroyed, but not easily created." ${ }^{4}$ One of the good things easily destroyed is beauty. Beauty is a vital component of human flourishing, and Scruton ruminated on beauty's meaning throughout his entire career. He knew that

2 Roger Scruton, The Meaning of Conservatism (South Bend, IN: St. Augustine Press), 60.

3 Roger Scruton, The Use of Pessimism (Oxford, England: Oxford University Press, 2010), 11-12.

4 Roger Scruton, Conservatism: Ideas in Profile (London, England: Profile Books, 2019), viii. 
beauty is an ultimate value-something that we pursue for its own sake, and for the pursuit of which no further reason need be given. Beauty should therefore be compared to truth and goodness, one member of a trio of ultimate values which justify our rational inclinations. ${ }^{5}$

Beauty is valuable unto itself, adding meaning without necessarily providing utility. Beauty's intrinsic value enables us to

appreciate beautiful things not for their utility only, but also for what they are in themselves-or more plausibly, for how they appear in themselves. ... When our interest is entirely taken up by a thing, as it appears in our perception, and independently of any use to which it might be put, then do we begin to speak of its beauty. ${ }^{6}$

Sir Roger emphasized the importance of our perceptions in determining the beauty of objects and our need to make things sacred. Scruton understood that "the sacred, like the beautiful, includes every category of object. . . Sacred things are not of this world: they are set apart from ordinary reality." ${ }^{7}$ The point of the sacred is to "make special" things, and the act of making things special "enhances group cohesion and also leads people to treat those things which really matter for the survival of the community." ${ }^{8}$ We have the ability to make things appear sacred to us. Ultimately, the sacred enables us to hold our communities and neighbors "together in times of threat."9

Sir Roger understood the need for community cohesion because he felt that our communities and their stability are the core of conservative thought, that "the most important input into conservative thinking is the desire to sustain the networks of familiarity and trust on which a community depends for its longevity." 10 Aware of what happens when these networks break down, Scruton knew the importance of ritual, tradition, and the sacred in securing stable communities, since "[s]ociety depends for its health and continuity on customs and

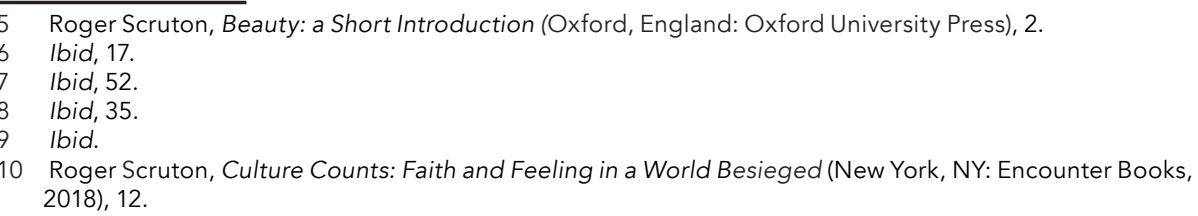


traditions that are at risk from individual freedom, even if they are also expressions of it."11

Mentioning the health of society and traditions in the same breath is not a coincidence but foundational to Scruton's thought. He was aware that traditions tacitly contain, "solutions tested by time and custom to the problems of social conflict and the needs of orderly government. It is the persistence of these institutions over time and their inscription in the hearts of the English people that have created the love of liberty." ${ }^{12}$

Scruton's emphasis on traditions, and the values latent in our traditions, emanates from the fact that "traditions are infinitely more than 'arbitrary rules and conventions.” Traditions are our society collectively “discussing answers that have been discovered to enduring questions. These answers are tacit, shared, embodied in social practices and inarticulate expectations."

Traditions enable social stability, and provide a stable environment for the individual to flourish within. They build and establish the necessary boundaries that limit our ability to stray too far from what is good, what is beautiful, and what is true. Without these boundaries, liberty degrades into license, and we engage in self-indulgent and self-destructive habits: "Social traditions exist because they enable a society to reproduce itself. Destroy them heedlessly and you remove the guarantee offered by one generation to the next." Traditions also connect the past with the present.

By abjuring our traditions, we run the risk of destroying not only our present security, but also the chance of prosperity for posterity. When we abandon our heritage, we are abandoning our culture. Scruton knew that culture is

the collective practice which renews those visions and extends our sympathies into all the corners of the heart. It is the ongoing record of the life of feeling, which offers to every new generation the examples, images, and words that will teach it what to feel. ${ }^{13}$

Communally agreed upon values further enable a community to perpetuate itself.

12 Roger Scruton, Conservatism: An Invitation to the Great Tradition (New York, NY: All Points Books, 2018).

13 Scruton, Culture Counts, 42. 
This is an issue Scruton well understood, and an issue we're dealing with in the most unpleasant ways at the moment. We are now-and more so today than in recent memory-dealing with a culture that cannot agree upon any mutually beneficial values. This is manifesting itself in is something known as "cancel culture," in which the internet mob attacks and tries to silence anything it finds offensive. One area in which this aggressive act of cancelation is occurring is comedy. Today, we can no longer laugh, let alone laugh together. "By laughing together at our faults," Scruton believed, "we come to accept them, and this makes cooperation with our imperfect neighbors easier, since it neutralizes anger at our shared inadequacies." Without the ability to laugh collectively, our anger and insecurities fester and eventually erupt, making stable and friendly communities impossible. Therefore, "a community of laughing people has a competitive advantage over a community of the humorless."14 Laughter matters. So too does our ability to laugh together, something we've all taken for granted. Laughter's importance is now painfully obvious in its absence.

And this is what everyone reading Sir Roger should take away from his lifetime of work: that the seemingly arbitrary things that our parents, grandparents, and ancestors had in their lives (which are the very same things we have in our lives) are not arbitrary, but in fact serve a purpose. The traditions, rituals, and institutions bequeathed to us by our ancestors shape and give meaning to our lives, from architecture to religion to laughter to drinking wine to hunting and even to sexual norms.

These ideas, institutions, and cultural forms are threatened, and as conservatives, it is our task to conserve them. Sir Roger knew that all that is worthy of sacrifice and heroism is present, but fading. We can recuperate, defend, and improve our troubled culture if we're willing to open our minds, and most of all, our hearts, to their possibilities.

Good things are easily destroyed, but not easily created indeed.

May Sir Roger Scruton's soul ascend.

14 Roger Scruton, On Human Nature (Princeton, NJ: Princeton University Press, 2018), 22. 